\title{
Ozone, water vapor, and temperature in the upper tropical troposphere: Variations over a decade of MOZAIC measurements
}

\author{
Sarah E. Bortz, ${ }^{1}$ Michael J. Prather, ${ }^{1}$ Jean-Pierre Cammas, ${ }^{2}$ Valérie Thouret, ${ }^{2}$ \\ and Herman Smit $^{3}$ \\ Received 19 July 2005; revised 16 September 2005; accepted 7 November 2005; published 3 March 2006.
}

[1] The MOZAIC (Measurement of Ozone and Water Vapor by Airbus In-service Aircraft) program (Marenco et al., 1998) has archived in situ measurements of temperature, water vapor, and ozone from August 1994 to December 2003. We analyze the trends, seasonality, and interannual variability of these quantities at aircraft cruise levels $(7.7-11.3 \mathrm{~km})$ within the tropics $\left(20^{\circ} \mathrm{S}-20^{\circ} \mathrm{N}\right)$. Mean lapse rates for temperature and $\log$ (water vapor) are nearly identical in both tropics. The root-mean-square variance in temperature over cruise levels, seasons, and years is small, $\leq 1^{\circ} \mathrm{C}$. The seasonal range in water vapor, a factor of 2.5 , is much larger than expected from the seasonal range in temperature $\left(1.7^{\circ} \mathrm{C}\right)$ if the two scale with the lapse rate relation or the Clausius-Clapeyron equation. The mean ozone abundance in the region sampled is $45 \mathrm{ppb}$ in the north tropics and $50 \mathrm{ppb}$ in the south tropics. This 112-month period shows a clearly linear increase in ozone over the north tropics with a trend fit of $1.12 \pm 0.05 \mathrm{ppb} / \mathrm{yr}$. In the south tropics, which has a large seasonal range of over $25 \mathrm{ppb}$, the trend is less obvious but still robust, $1.03 \pm 0.08 \mathrm{ppb} / \mathrm{yr}$. These trends in the upper troposphere are twice as large as reported for surface ozone over the tropical Atlantic (Lelieveld et al., 2004), but this pattern of ozone increases is consistent with projected increases driven by industrial emissions.

Citation: Bortz, S. E., M. J. Prather, J.-P. Cammas, V. Thouret, and H. Smit (2006), Ozone, water vapor, and temperature in the upper tropical troposphere: Variations over a decade of MOZAIC measurements, J. Geophys. Res., 111, D05305, doi:10.1029/2005JD006512.

\section{Introduction}

[2] The tropical troposphere dominates the photochemistry and energy budgets of the atmosphere. Knowledge of the response of this region to evolving anthropogenic emissions of reactive gases as well as to climate change and variability is important for the understanding and prediction of global change. Long-term climate records of the upper tropical troposphere, particularly in situ measurements of temperature, water vapor, and ozone, have been sparse. The MOZAIC (Measurement of Ozone and Water Vapor by Airbus In-service Aircraft) program now covers more than a decade with stable, precise measurements of these variables in the middle and upper troposphere as well as in the lower stratosphere at mid and northern latitudes [Marenco et al., 1998]. In terms of ozone, recent MOZAIC publications focus on the North Atlantic Flight Corridor, midlatitude profiles over airports, equatorial Africa, and comparison with SHADOZ (Southern Hemisphere Additional Ozone-

\footnotetext{
${ }^{1}$ Earth System Science Department, University of California, Irvine, Irvine, California, USA.

${ }^{2}$ Laboratorie d'Aérologie, Toulouse, France.

${ }^{3}$ Research Center Jülich GmbH, Jülich, Germany.
}

Copyright 2006 by the American Geophysical Union. 0148-0227/06/2005JD006512 sondes) data [Thouret et al., 2005; Sauvage et al., 2005]. Here, we study the measurements taken at aircraft cruise levels $(196-330 \mathrm{hPa})$ well within the tropics $\left(20^{\circ} \mathrm{S}-20^{\circ} \mathrm{N}\right)$, constituting about $6 \%$ of all data, and we present the trends, seasonality, and interannual variability within this restricted domain.

[3] The measurements and methods used to analyze the archived MOZAIC data are described in section 2, along with comments on the basic statistics such as the narrow seasonal amplitude in temperature $\left(1^{\circ} \mathrm{C}\right)$ compared with that in water vapor. Section 3 examines the full decadal temperature record, noting that the month-to-month variability is similar in both hemispheres and matches the satellite Microwave Sounding Unit (MSU) channel 2 record [Christy et al., 2000; Mears et al., 2003]. In section 4, water vapor is found to vary differently than expected from the lapse rate relation or Clausius-Clapeyron equation, on all scales. Upper tropospheric ozone, although distinctly different between hemispheres, is found in section 5 to have the same linear rate of increase of about $1 \mathrm{ppb} / \mathrm{yr}$ in both north and south tropics. Interpretation of these patterns is discussed in the concluding section 6 .

\section{Measurements and Methods}

[4] The MOZAIC program was initiated in 1993 by European scientists, aircraft manufacturers, and commercial 


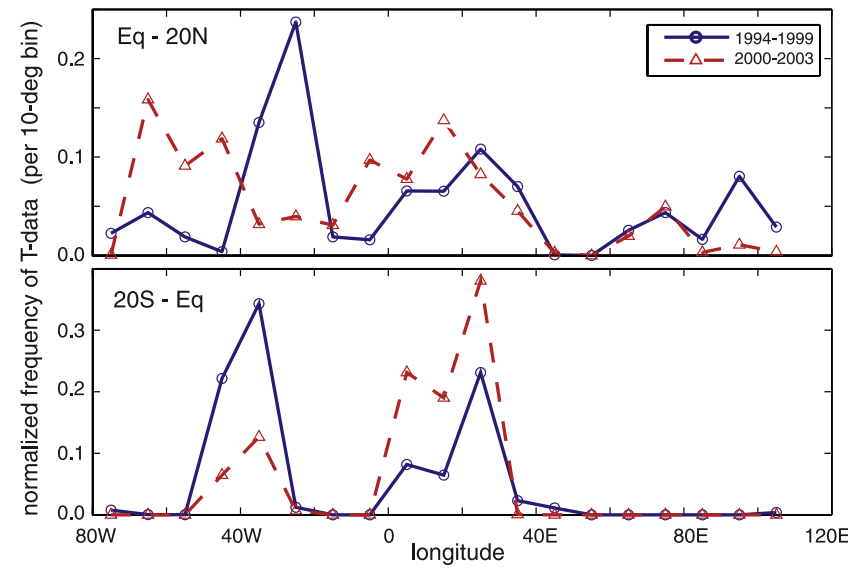

Figure 1. Normalized longitudinal distribution of MOZAIC temperature data at cruise levels in the North (upper panel, $0-20^{\circ} \mathrm{N}$ ) and South Tropics (lower, $0-20^{\circ} \mathrm{S}$ ) during 1994-1999 (solid, blue circles) and 2000-2003 (dashed, red triangles).

airlines to understand how human activity, particularly air traffic, is affecting the atmosphere. MOZAIC makes continuous, automated measurements on five long-range Airbus A340 aircraft of ozone, water vapor, nitrogen oxides, carbon monoxide, temperature, pressure, wind speeds, and flight positions [Marenco et al., 1998]. Temperature is measured with a platinum resistance sensor (Pt100) that has an estimated uncertainty of $\pm 0.1^{\circ} \mathrm{C}$ [Helten et al., 1998]. Water vapor is measured by a capacitive sensor (Humicap-H) with a hydroactive polymer film that has a mean overall uncertainty of $4-7 \%$ in relative humidity and a specific humidity detection limit of $0.001 \mathrm{~g} / \mathrm{kg}$
[Helten et al., 1998]. Ozone is measured by a dual-beam UV-absorption analyzer with an overall precision of $\pm(2 \mathrm{ppb}+2 \%)$ [Thouret et al., 1998a]. The sensors are recalibrated after every 500 flight hours.

[5] Regular flights began in August 1994, and through December 2003 there were 21,902 flights recorded spanning cities across Europe, North America, South America, Africa, and Asia (http://www.aero.obs-mip.fr/mozaic/). Although the tropical cruise data from MOZAIC make up only $6 \%$ of all data, they include tens of millions of individual 4-s measurements for the 112-month period. We use the M-data records, which consist of 1-min averages $(\sim 15 \mathrm{~km}$ distance at cruise $)$ of the highresolution measurements, resulting in about 1 million records with valid temperature, water vapor, or ozone data between $20^{\circ} \mathrm{S}$ and $20^{\circ} \mathrm{N}$. We select only data at cruise levels $(196-330 \mathrm{hPa})$, which make up $71 \%$ of all tropical records. Typically, valid temperature measurements are available on $95 \%$ of these records, and all three quantities occur on $88 \%$.

[6] Measurements taken between $0^{\circ}-20^{\circ} \mathrm{N}$ and $0^{\circ}-$ $20^{\circ} \mathrm{S}$ are labeled here as the North Tropics (NTr) and South Tropics (STr), respectively. Most data in the tropics are taken at cruise levels [e.g., Thouret et al., 1998b], where a constant pressure level is maintained to within $\pm 50 \mathrm{~m}$. Table 1 shows the cruise levels, the corresponding pressure altitudes, and the number of 1-min temperature data at each level, summed over the 112 -month period. The longitudinal distributions of data for the first (1994-1999) and second (2000-2003) halves of the time series are shown in Figure 1. In the NTr the distribution shifted during 2000-2003 when flights to northern South America were added, and several flights to southeast Asia were dropped. In the STr the distribution of flights shifted from South America to southern Africa.

Table 1. MOZAIC Mean Values for $\mathrm{T},{ }^{\circ} \mathrm{C}, \mathrm{q}, \mathrm{g} / \mathrm{kg}, \log _{10}(\mathrm{q})$, and $\mathrm{O}_{3}, \mathrm{ppb}$, at Cruise Levels in the South $(0-$ $\left.20^{\circ} \mathrm{S}\right)$ and North Tropics $\left(0-20^{\circ} \mathrm{N}\right)$ for the Period August 1994 to December $2003^{\mathrm{a}}$

\begin{tabular}{|c|c|c|c|c|c|c|}
\hline $\mathrm{P}, \mathrm{hPa}$ & $\mathrm{z}^{*}, \mathrm{~km}$ & Number of Points & $\mathrm{T},{ }^{\circ} \mathrm{C}$ & $\mathrm{q}, \mathrm{g} / \mathrm{kg}$ & $\log 10(q)$ & $\mathrm{O}_{3}, \mathrm{ppb}$ \\
\hline \multicolumn{7}{|c|}{$0-20^{\circ} S(S T r)$} \\
\hline 196 & 11.3 & 46126 & $-54.6 \pm 0.4$ & 0.033 & $-1.48 \pm 0.13$ & $50.8 \pm 8.7$ \\
\hline 216 & 10.6 & 27355 & $-48.7 \pm 0.8$ & 0.068 & $-1.17 \pm 0.13$ & $52.3 \pm 7.4$ \\
\hline 238 & 9.9 & 54791 & $-43.8 \pm 0.6$ & 0.090 & $-1.05 \pm 0.17$ & $48.9 \pm 8.1$ \\
\hline 262 & 9.3 & 67382 & $-38.8 \pm 0.6$ & 0.129 & $-0.89 \pm 0.14$ & $48.6 \pm 8.8$ \\
\hline 287 & 8.6 & 13252 & $-32.9 \pm 0.8$ & 0.212 & $-0.67 \pm 0.24$ & $54.6 \pm 10.9$ \\
\hline 316 & 8.0 & 10758 & $-28.6 \pm 0.8$ & 0.271 & $-0.57 \pm 0.20$ & $49.1 \pm 7.5$ \\
\hline 330 & 7.7 & 861 & $-26.0 \pm 0.5$ & 0.340 & $-0.47 \pm 0.32$ & $56.2 \pm 7.7$ \\
\hline Summaries & & 220525 & $-7.9^{\circ} \mathrm{C} / \mathrm{km}$ & & $-0.28 / \mathrm{km}$ & 50.0 \\
\hline \multicolumn{7}{|c|}{$0-20^{\circ} N(N T r)$} \\
\hline 196 & 11.3 & 34452 & $-54.2 \pm 0.3$ & 0.044 & $-1.36 \pm 0.08$ & $45.9 \pm 2.4$ \\
\hline 216 & 10.6 & 102021 & $-48.9 \pm 0.6$ & 0.065 & $-1.19 \pm 0.09$ & $45.2 \pm 2.8$ \\
\hline 238 & 9.9 & 146342 & $-44.0 \pm 0.5$ & 0.095 & $-1.02 \pm 0.05$ & $44.9 \pm 2.2$ \\
\hline 262 & 9.3 & 97781 & $-38.6 \pm 0.6$ & 0.149 & $-0.83 \pm 0.06$ & $43.8 \pm 2.6$ \\
\hline 287 & 8.6 & 35564 & $-32.7 \pm 1.0$ & 0.229 & $-0.64 \pm 0.18$ & $44.0 \pm 3.8$ \\
\hline 316 & 8.0 & 6645 & $-28.1 \pm 1.0$ & 0.352 & $-0.45 \pm 0.14$ & $43.8 \pm 2.8$ \\
\hline 330 & 7.7 & 9423 & $-24.9 \pm 1.4$ & 0.471 & $-0.33 \pm 0.27$ & $44.3 \pm 5.5$ \\
\hline Summaries & & 432228 & $-8.1^{\circ} \mathrm{C} / \mathrm{km}$ & & $-0.29 / \mathrm{km}$ & 44.7 \\
\hline
\end{tabular}

${ }^{a}$ The rms variance (except for $\mathrm{q}$ ) follows the \pm symbol. The number of 1-min records with $\mathrm{T}$ data are shown for each cruise level and summed. The altitude $\mathrm{z}^{*}=16 \log _{10}(1000 / \mathrm{p}) \mathrm{km}$. The mean lapse rate for $\mathrm{T}$ and $\log _{10}(\mathrm{q})$, and the mean $\mathrm{O}_{3}$, are also shown. All means and variances are point-weighted. 
Table 2. Seasonal Cycles in $\mathrm{T},{ }^{\circ} \mathrm{C}, \log _{10}(\mathrm{q})$, and $\mathrm{O}_{3}, \mathrm{ppb}$, Averaged Over MOZAIC Cruise Levels $(7.7-11.3 \mathrm{~km})$ in the South and North Tropics ${ }^{\mathrm{a}}$

\begin{tabular}{lccc}
\hline & $\mathrm{T},{ }^{\circ} \mathrm{C}$ & $\log 10(\mathrm{q})$ & $\mathrm{O}_{3}, \mathrm{ppb}$ \\
\hline & & $0-20^{\circ} \mathrm{S}(\mathrm{STr})$ & \\
Jan & +0.05 & +0.14 & 45.8 \\
Feb & +0.40 & +0.09 & 49.0 \\
Mar & +0.86 & +0.15 & 41.6 \\
Apr & +0.56 & +0.03 & 42.2 \\
May & +0.50 & -0.10 & 42.9 \\
Jun & +0.09 & -0.25 & 49.9 \\
Jul & -0.98 & -0.23 & 51.8 \\
Aug & -1.04 & -0.19 & 53.5 \\
Sep & -0.27 & -0.06 & 61.9 \\
Oct & -0.20 & +0.05 & 67.8 \\
Nov & -0.15 & +0.10 & 58.6 \\
Dec & +0.06 & & 52.8 \\
& & & \\
Jan & -0.57 & -0.16 & 41.4 \\
Feb & -0.41 & -0.15 & 41.2 \\
Mar & -0.24 & -0.12 & 44.1 \\
Apr & +0.22 & -0.06 & 45.5 \\
May & +0.68 & -0.05 & 48.9 \\
Jun & +0.67 & +0.01 & 47.9 \\
Jul & +0.54 & +0.08 & 44.8 \\
Aug & +0.45 & +0.06 & 43.2 \\
Sep & +0.37 & +0.02 & 44.4 \\
Oct & -0.18 & -0.01 & 45.0 \\
Nov & -0.67 & -0.02 & 44.6 \\
Dec & -0.93 & -0.08 & 43.6 \\
\hline
\end{tabular}

${ }^{\mathrm{a}}$ For $\mathrm{T}$ and $\log _{10}(\mathrm{q})$ the values are deviations from the mean, see text.

[7] The mean vertical structures of temperature $\left(\mathrm{T},{ }^{\circ} \mathrm{C}\right)$, water vapor mixing ratio $(\mathrm{q}, \mathrm{g} / \mathrm{kg}), \log _{10}(\mathrm{q})$, and ozone abundance $\left(\mathrm{O}_{3}, \mathrm{ppb}\right)$, as sampled at cruise levels in the $\mathrm{NTr}$ and STr, are given in Table 1. The mean values of all four quantities are shown, along with the root-meansquare (rms) variances for $\mathrm{T}, \log _{10}(\mathrm{q})$, and $\mathrm{O}_{3}$, and the number of data points. There are almost twice as many measurements in the NTr as in the STr. Excluding the undersampled, 7.7-km cruise level, the rms variance in $\mathrm{T}$ over the entire MOZAIC data set at cruise levels is small, less than or equal to $1^{\circ} \mathrm{C}$. Water vapor is more variable at lower cruise levels, and the variability of both water vapor and ozone is consistently greater in the STr. Approximate lapse rates for $\mathrm{T}$ and $\log _{10}(\mathrm{q})$, are nearly identical in the NTr and STr. As noted by Thouret et al. [1998a], there is no clear vertical structure for $\mathrm{O}_{3}$, although the mean abundance in the STr is about $5 \mathrm{ppb}$ higher than that in the NTr. Earlier MOZAIC studies of tropospheric $\mathrm{O}_{3}$ developed several different approaches to remove stratospheric data [Gierens et al., 1997; Thouret et al., 1998a; Stohl et al., 2001], but since stratospheric air is rare at cruise levels in the tropics, we simply filter out records with $\mathrm{O}_{3} \geq 100 \mathrm{ppb}$. This filter indiscriminately removes stratospheric air as well as biomass burning or urban pollution plumes but removes less than $0.5 \%$ of our records.

[8] The seasonal patterns of $\mathrm{T}, \mathrm{q}$, and $\mathrm{O}_{3}$ for this mid-toupper region of the tropical troposphere $(7.7-11.3 \mathrm{~km})$ are derived by combining all cruise levels. In each tropical band, we compute a point-weighted, monthly average of $\mathrm{T}$, $\log _{10}(\mathrm{q})$, and $\mathrm{O}_{3}$ at each cruise level. The monthly deviation from the annual mean value (Table 1) is then averaged across all cruise levels (point-weighted again) to derive a more robust seasonal cycle as shown in Table 2 . For $\mathrm{O}_{3}$ the seasonal cycle is computed in absolute abundance. In terms of temperature and water vapor, the NTr and STr are not precisely 6 months out-of-phase, but the expected positive (negative) variations in $\mathrm{T}$ and $\mathrm{q}$ do occur during the respective hemisphere's summers (winters). The seasonal amplitude of $\mathrm{T}$ in both tropics is small, about $1^{\circ} \mathrm{C}$. However, the seasonal amplitude of $\log _{10}(\mathrm{q})$ is about 0.2 , much larger than expected from the seasonal amplitude of $\mathrm{T}$ if the two scale with the lapse rate relation or the Clausius-Clapeyron equation (e.g., 0.04 , or a $10 \%$ increase in q per $1^{\circ} \mathrm{C}$ increase in this region). This indicates that the mean vertical profile of water vapor may be controlled by deep moist convection (i.e., a wet adiabatic lapse rate) but that much of the variability is driven by nonmoist, large-scale motions. The seasonal cycle of the MOZAIC-sampled $\mathrm{O}_{3}$ is not apparent in the NTr, in part because flights over South America and Africa show different seasonality (see later discussion). The seasonal range in the $\mathrm{STr}$ is large, $26 \mathrm{ppb}$, with similar magnitude and phase over both South America and southern Africa and with peak values during September-OctoberNovember associated with biomass burning [Logan and Kirchhoff, 1986; Thompson et al., 1996; Bremer et al., 2004].

\section{Temperature Variability}

[9] Temperature variations and trends in the upper tropical troposphere remain key to understanding climate change [Santer et al., 2004]. There has been substantial disagreement over the trends in this region, particularly for midtropospheric temperatures from the MSU channel 2 [Christy et al., 2000; Mears et al., 2003; Vinnikov and Grody, 2003; Fu and Johanson, 2005]; however, recent reanalyses of the MSU data coupled with model results and radiosonde data have identified warming in all layers of the tropical troposphere that is physically consistent with warming at the surface [Mears and Wentz, 2005; Santer et al., 2005; Sherwood et al., 2005]. Since the MOZAIC cruise levels overlap with the maximum of the vertical weighting function for MSU channel 2 $(\sim 350 \mathrm{hPa})$, we develop an equivalent data set of tropical temperatures for comparison. Monthly temperature anomalies for the 112-month MOZAIC period of August 1994 through December 2003 are calculated by subtracting the overall mean for each cruise level and the mean seasonal cycle for each month at that level (given in Tables 1 and 2). The temperature anomalies are then combined, point-weighted, for all cruise levels. There are clear longitudinal variations of temperature in the tropics, and these anomalies are correlated with the mean longitude of MOZAIC measurements for the month: $+0.023^{\circ} \mathrm{C}$ per degree longitude for a range of mean longitudes from $50^{\circ} \mathrm{W}$ to $70^{\circ} \mathrm{E}$ in the $\mathrm{NTr}$ and $+0.012^{\circ} \mathrm{C}$ per degree longitude from $40^{\circ} \mathrm{W}$ to $30^{\circ} \mathrm{E}$ in the STr. After correction for longitude bias, the resulting anomalies for the $\mathrm{NTr}$ (blue squares) and STr (red triangles) are plotted in Figure 2a. Similar to the observations of Reid et al. [1989] over the equatorial Pacific, the hemisphere's anomalies track one another, indicating that the interan- 


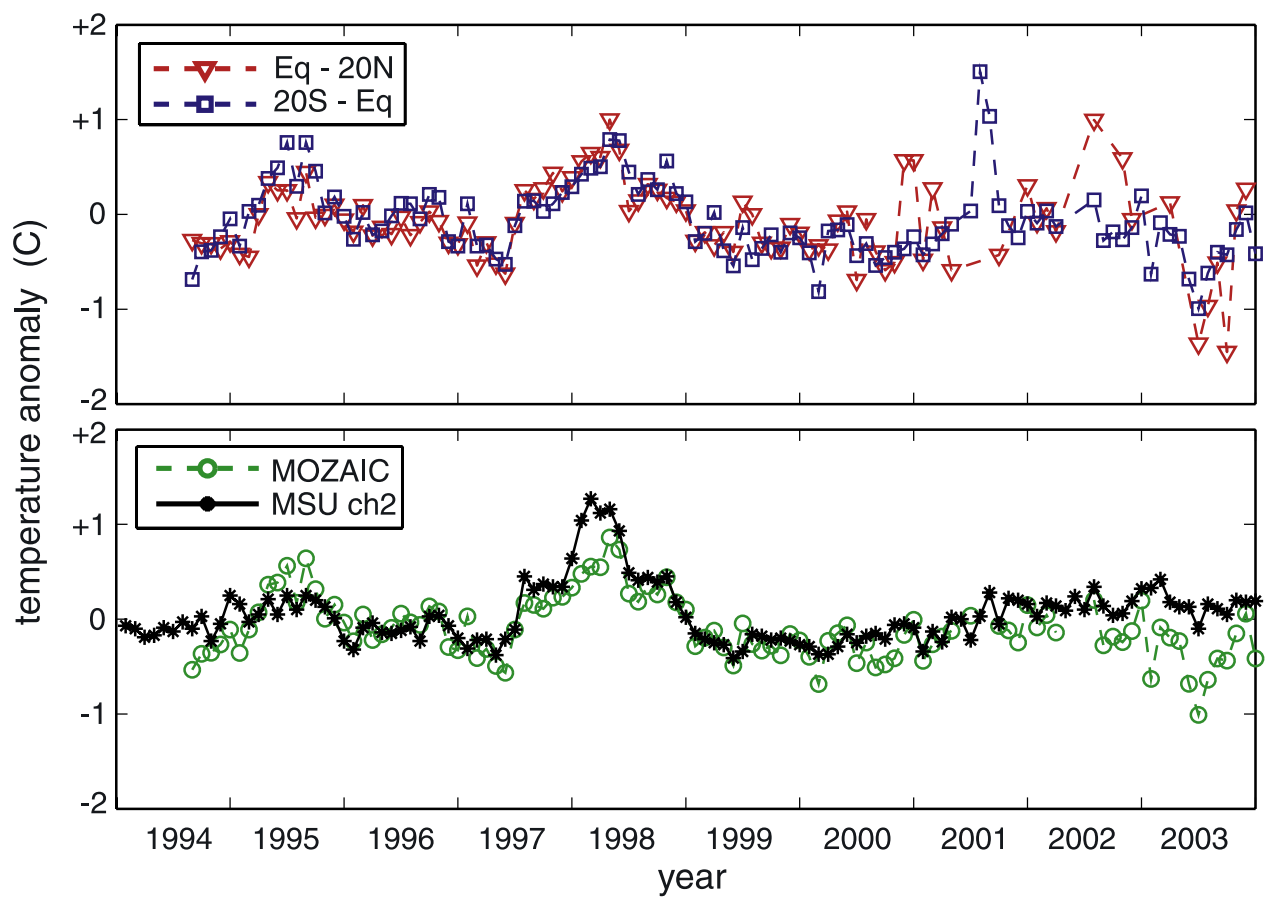

Figure 2. (a) Temperature anomalies from MOZAIC cruise levels $(7.7-11.3 \mathrm{~km})$ in North $\left(0-20^{\circ} \mathrm{N}\right.$, blue squares) and South Tropics $\left(0-20^{\circ} \mathrm{S}\right.$, red triangles). The monthly anomalies for the period August 1994 through December 2003 have the mean seasonality, mean lapse rate, and longitudinal sampling bias removed. Several months starting May 2001 have no data and are not plotted. The months July-August 2001 in the North Tropics are extremely undersampled ( $<1 \%$ of average rate) and not shown below. (b) Combined MOZAIC tropical temperature anomalies (point-weighted, green circles) and the MSU channel 2 tropical $\left(30^{\circ} \mathrm{S}-30^{\circ} \mathrm{N}\right)$ temperature anomalies (black asterisks) taken from the RSS record, see text.

nual variation in upper-tropospheric temperatures is coupled across the equator. By early 2001, the number of MOZAIC flights dropped dramatically, and several months such as May 2001 have no flights in the tropics. The exceptional NTr points in Figure 2a are the months July and August 2001, which had only 300 and 113 records, respectively, compared with the monthly average of 3700. For the NTr (but not the STr) the frequency of flights increased in 2003 and the monthly anomalies are again well defined.

[10] The combined, point-weighted NTr-plus-STr temperature anomalies are plotted in Figure $2 \mathrm{~b}$ (green circles) together with the tropical $\left(30^{\circ} \mathrm{S}-30^{\circ} \mathrm{N}\right)$ MSU channel 2 temperature anomalies (black asterisks) (data from Remote Sensing Systems; analysis from J. Penner, private communication, 2004). The undersampled months July and August 2001 have been dropped. Both sets show remarkably similar temperature anomalies in absolute magnitude and in phase. The 1995 warming event is larger in MOZAIC than in MSU, but the 1997-1998 El Niño warming of the upper tropical troposphere is similar in both. We conclude that the MOZAIC record, at least in terms of temperature, is representative of the upper tropical troposphere. Along with the sonde data [Seidel et al., 2001], it provides independent corroboration of the MSU channel 2 tropical temperature anomalies. Without more detailed comparisons, focusing on specific overpasses by the different MSU satellites of the aircraft flights, the MOZAIC data cannot contribute to the debate over the long-term precision of the MSU record because of its relatively short period (10 versus 25 years) and geographic sampling bias.

\section{Water Vapor Variability}

[11] Changes in water vapor in the upper tropical troposphere, where it is an important greenhouse gas, are expected by most climate models to accompany global warming [e.g., Stocker et al., 2001, Figure 7.1; Held and Soden, 2000]. Observational studies have attempted to examine the response of atmospheric humidity to changes in surface temperature [Sun and Oort, 1995; Soden et al., 2002] but results have been inconclusive.

[12] The MOZAIC specific humidity data (q) are reported as mass mixing ratios $\left(\mathrm{g}-\mathrm{H}_{2} \mathrm{O} / \mathrm{kg}\right.$-air). We find that $\log _{10}(\mathrm{q})$ has a well defined, linear lapse rate over the cruise levels and, in most cases, has a symmetric probability distribution. Exceptions occur during the summer months in both tropics under conditions of high relative humidity when the upper ends of the probability distributions are cut off about the ice supersaturation threshold. The mean seasonal cycle of water vapor at the top six cruise levels is shown as a $\log _{10}(\mathrm{q})$ versus $\mathrm{T}$ plot in Figure $3 \mathrm{a}(\mathrm{NTr})$ and $3 \mathrm{~b}(\mathrm{STr})$. The dashed lines in Figure 3 represent 100\% (upper), 50\%, and 30\% (lower) supersaturation with respect to ice [Goff and 


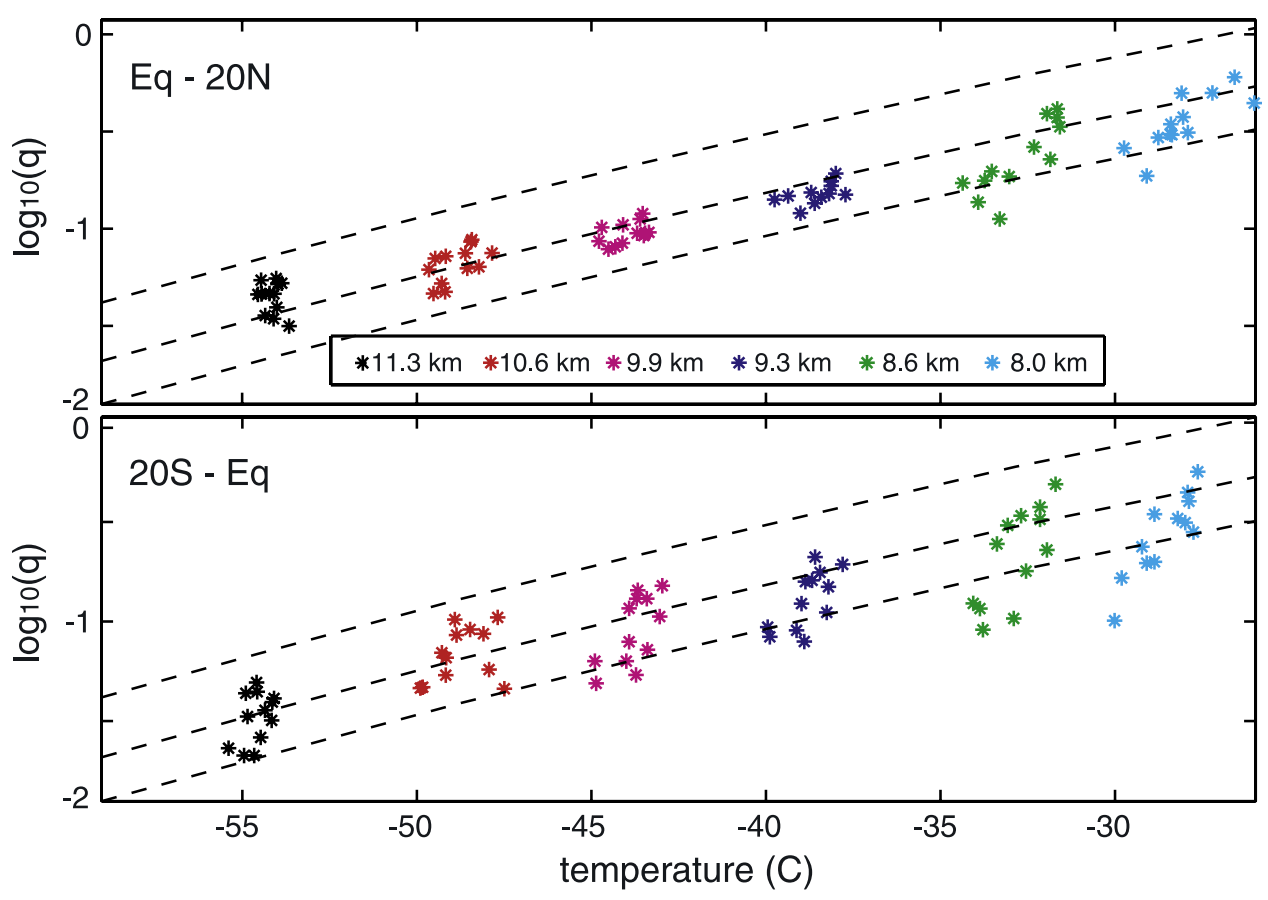

Figure 3. Mean seasonal cycle of $\log _{10}(\mathrm{q}$, in $\mathrm{g} / \mathrm{kg})$ versus $\mathrm{T}\left({ }^{\circ} \mathrm{C}\right)$ at the upper six MOZAIC cruise levels $(8.0-11.3 \mathrm{~km})$ for the North Tropics $\left(0-20^{\circ} \mathrm{N}\right.$, upper panel) and South Tropics $\left(0-20^{\circ} \mathrm{S}\right.$, lower panel). The corresponding $100 \%$ (uppermost), $50 \%$, and $30 \%$ (lowermost) Goff-Gratch ice saturation lines are superimposed. Generally, highest $\log _{10}(\mathrm{q})$ values correspond to the summer months; and lowest, to winter.

Gratch, 1946]. The mean values at each cruise level tend to follow the relative humidity lines. However, with the exception of the two NTr middle cruise levels, the seasonal cycles at each level do not. Thus at most cruise levels, there is a large cycle in water vapor (and relative humidity) with the lowest values occurring in the winters and the highest values in the summers (see Table 2).

[13] The water vapor anomalies, constructed in parallel with the temperature anomalies in Figure 2a, show high interannual variability, and are not presented here. Over the 112 months, the deseasonalized, interannual variations span a factor of 2.5 (peak-to-peak) and show multiyear correlations in both hemispheres, but no obvious trends in water vapor can be seen. We examine the correlation between the temperature and water vapor anomalies over the 112-month period in Figure 4 to test whether interannual changes follow the q-T relative humidity relation. The dashed line plotted through the center in Figure 4 represents this idealized relation at these temperatures. These monthly anomalies, like the seasonal cycle, show much greater variance in water vapor than temperature, if relative humidity were constant. A linear regression of $\log _{10}(\mathrm{q})$ versus $\mathrm{T}$ has a slope similar to the relative humidity line but explains little of the variance in $\mathrm{q}$. While the lapse rate and the variations over the 1997-1998 El Niño show the expected q-T correlation, most of the variability in water vapor (larger than during the El Niño) appears independent of $\mathrm{T}$ and is likely driven by large-scale motions, e.g., uplift in the summer hemisphere and subsidence and/or extensive horizontal mixing with the dry subtropics during winter [e.g., Minschwaner and Dessler, 2004]. A simple, wet convective coupling throughout the tropical troposphere cannot explain this pattern in water vapor.

\section{Ozone Patterns, Variability, and Trends}

[14] The regular geographic-and-seasonal pattern of tropospheric $\mathrm{O}_{3}$ over the tropics is attributable to biomass burning and lightning emissions of $\mathrm{O}_{3}$ precursors plus large-

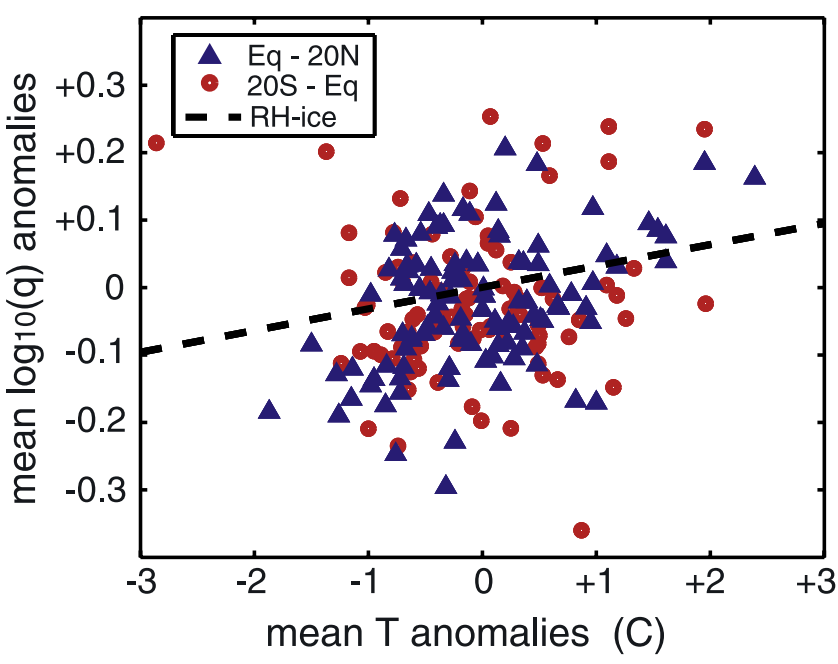

Figure 4. Monthly anomalies in $\log _{10}(\mathrm{q})$ versus $\mathrm{T}\left({ }^{\circ} \mathrm{C}\right)$ for North $\left(0-20^{\circ} \mathrm{N}\right.$, blue triangles) and South Tropics $\left(0-20^{\circ} \mathrm{S}\right.$, red circles) averaged over MOZAIC cruise levels for the period August 1994 through December 2003. An approximate constant relative humidity line (dashed) is shown. 


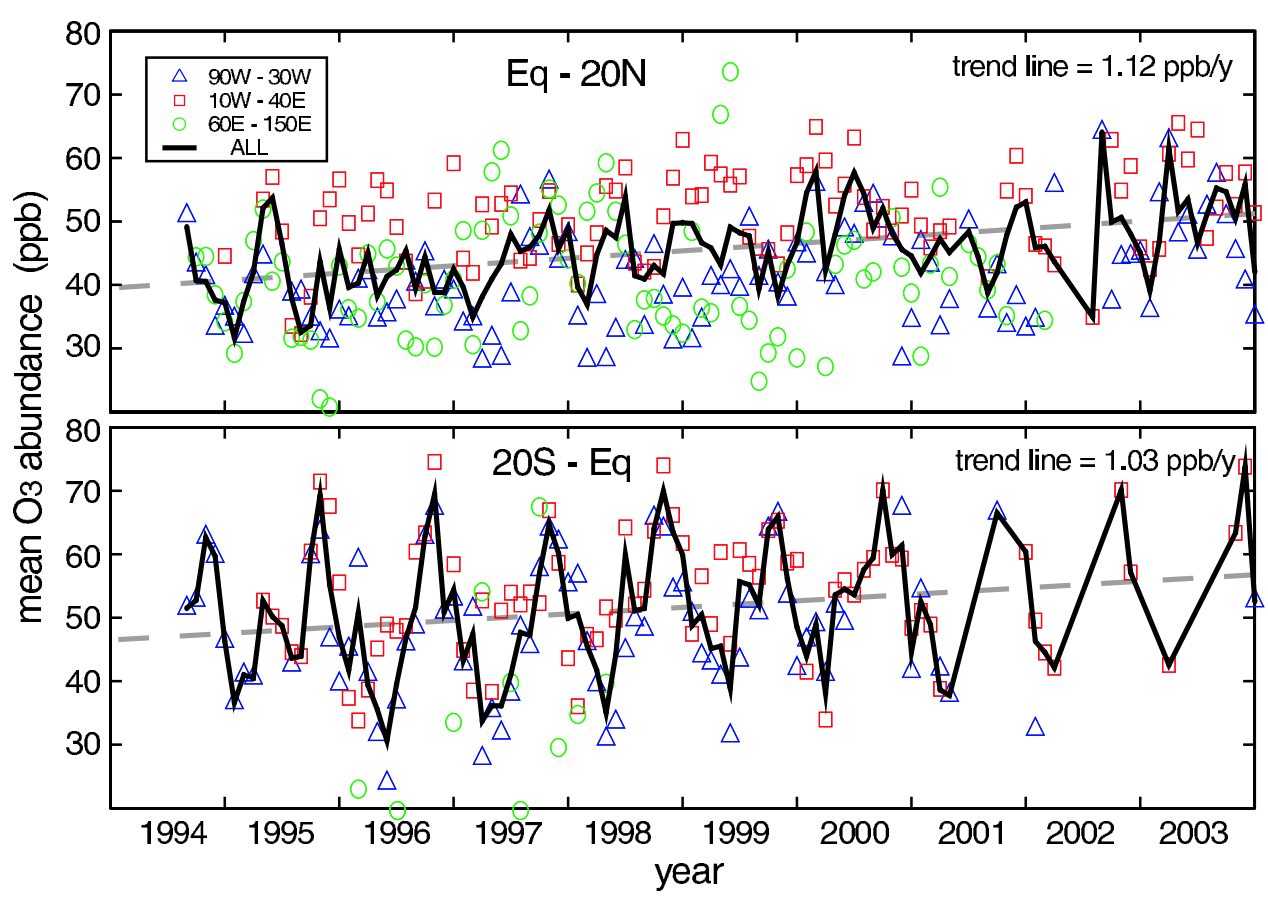

Figure 5. Monthly mean $\mathrm{O}_{3}$ mole fraction (ppb) averaged over MOZAIC cruise levels for the period August 1994 through December 2003 and for the North (upper panel, $0-20^{\circ} \mathrm{N}$ ) and South Tropics (lower, $0-20^{\circ} \mathrm{S}$ ). The point-weighted mean of all observations (thick black dashed line) is shown with the monthly means for specific longitude domains: South America $\left(90^{\circ} \mathrm{W}-30^{\circ} \mathrm{W}\right.$, blue triangles), Africa $\left(10^{\circ} \mathrm{W}-40^{\circ} \mathrm{E}\right.$, red squares), and Asia $\left(60^{\circ} \mathrm{E}-150^{\circ} \mathrm{E}\right.$, green circles). A linear regression (gray line) through the overall means gives a slope of $1.12 \pm 0.05 \mathrm{ppb} / \mathrm{yr}(\mathrm{NTr})$ and $1.03 \pm 0.08 \mathrm{ppb} / \mathrm{yr}$ (STr). Uncertainties are one-sigma and assume each monthly point is exact and independent.

scale transport, and a prominent feature is the large positive $\mathrm{O}_{3}$ anomaly over the Atlantic [Logan and Kirchhoff, 1986; Fishman and Brackett, 1997; Martin et al., 2000; Chandra et al., 2003; Thompson et al., 2003; Peters et al., 2004; B. Sauvage et al., Enhanced view of the Tropical Atlantic Ozone Paradox and Zonal Wave-One from the in situ MOZAIC and SHADOZ data, submitted to Journal of Geophysical Research, 2006]. Analysis of the early MOZAIC measurements (1994-1996) found $\mathrm{O}_{3}$ to be vertically homogeneous and apparently well mixed at cruise levels [Thouret et al., 1998b], results that are consistent with sonde data from a limited number of tropical sites [Logan, 1999] and with the extended MOZAIC record shown here (see Table 1). Thouret et al. [2005] developed a midlatitude climatology for $\mathrm{O}_{3}$ in the upper troposphere and lower stratosphere from the 1994-2003 MOZAIC data. This work uses this extended data set, focusing on the deep tropics $\left(20^{\circ} \mathrm{S}-20^{\circ} \mathrm{N}\right)$ where stratospheric influence is remote.

[15] In the $\mathrm{STr}$, mean $\mathrm{O}_{3}$ abundances at cruise levels are consistently higher and the seasonal cycles are more regular than in the NTr. The average of the NTr has surprisingly little seasonality at MOZAIC cruise levels, but when the $\mathrm{NTr}$ data are separated into three longitude regions (South America, Africa, and Asia, see Figure 5) some mix of seasonality and interannual variability is apparent. In the $\mathrm{STr}$, the seasonal patterns over South America and Africa are similar, and there is a clear maximum during the biomass burning in September-October-November as first noted in the sonde data. Given the limited longitudinal sampling with the gap over the south Atlantic (see Figure 1) and the known longitudinal structures in tropical tropospheric $\mathrm{O}_{3}$, some caution should be taken in extrapolating the MOZAIC climatology and trends to the entire tropics.

[16] Long-term, climate records able to show $\mathrm{O}_{3}$ changes in the upper troposphere are rare. A multisite sonde record of middle- and upper-tropospheric ozone is only available at northern midlatitudes $\left(1970-1998,36^{\circ} \mathrm{N}-59^{\circ} \mathrm{N}\right)$ [Logan et al., 1999]. It shows considerable interannual variability, but is consistent with a small trend (J. A. Logan, private communication, 2005) [Prather et al., 2001, Figure 4.8]. The 112-month record of tropical tropospheric $\mathrm{O}_{3}$ at MOZAIC cruise levels is shown in Figure 5 for both the $\mathrm{NTr}$ (top) and STr (bottom). These data have not been adjusted in any way. The point-weighted means of all cruise level observations (thick black dashed line) are shown along with the monthly means for specific longitude domains: South America $\left(90^{\circ} \mathrm{W}-30^{\circ} \mathrm{W}\right.$, blue triangles), Africa $\left(10^{\circ} \mathrm{W}-40^{\circ} \mathrm{E}\right.$, red squares), and Asia $\left(60^{\circ} \mathrm{E}-150^{\circ} \mathrm{E}\right.$, green circles). There is much greater variability for these restricted longitude ranges, but many months have few or no data. In the NTr the mean $\mathrm{O}_{3}$ is much smoother, in part because of different seasonality and in part because of better statistics. A linear regression (gray line) gives a slope of $1.12 \pm$ $0.05 \mathrm{ppb} / \mathrm{yr}$ (uncertainties are one-sigma and assume each monthly point is independent). In the STr the linear increase is less apparent because of the large seasonality but is similar $1.03 \pm 0.08 \mathrm{ppb} / \mathrm{yr}$. These uncertainties are underestimated because the variability is clearly correlated over seasons in both hemispheres and in the STr the end of the record has few data. We are also concerned that the 
longitudinal shift in the MOZAIC flights, combined with the known longitudinal structure in $\mathrm{O}_{3}$, may have generated false trends. This is unlikely since the longitudinal shift of the flights was not regular, the shift affected each hemisphere differently, and a plot of monthly mean $\mathrm{O}_{3}$ versus monthly mean flight-longitude does not produce any notable correlation. Further, a linear fit to the NTr data over Africa (red squares in Figure 5), for which we have a sufficient number of flights, produces a similar but more uncertain slope, $0.95 \pm 0.38 \mathrm{ppb} / \mathrm{yr}$.

[17] Combining all evidence, we believe that the MOZAIC data show a $20 \%$ increase in upper tropospheric $\mathrm{O}_{3}$ over a large region of the tropics that has occurred linearly over the last decade. While the large seasonality and year-to-year variations seen in Figure 5 are likely driven by natural changes in circulation and biomass burning, the regular increase points to anthropogenic emissions of $\mathrm{O}_{3}$ precursors. Lelieveld et al. [2004] analyzed shipboard $\mathrm{O}_{3}$ measurements over the Atlantic Ocean from 1977 to 2002 and finds large increases of $13 \mathrm{ppb}$ (over 25 years) at the surface over the latitude range $20^{\circ} \mathrm{N}-40^{\circ} \mathrm{N}$ and $11 \mathrm{ppb}$ over the range $0-20^{\circ} \mathrm{N}$, which they attribute to increasing industrial emissions of $\mathrm{NO}_{x}$ and other $\mathrm{O}_{3}$ precursors in the tropics. In contrast, analysis of the tropospheric $\mathrm{O}_{3}$ column from TOMS (Total Ozone Mapping Spectrometer) measurements [Ziemke et al., 2005] specifically notes the lack of any trend in the tropics for the period 1979-2003. These two results have been reconciled by noting that the surface and column changes need not be proportional; however, such an interpretation is not consistent with our findings. If we focus on the recent decade of MOZAIC data, a period for which we have the most extensive shipboard [Lelieveld et al., 2004, Figure 2], satellite, and sonde measurements [Ziemke et al., 2005, Figure 5a], then all three data sets look more congruous and support a steady but nonuniform rise in tropical tropospheric $\mathrm{O}_{3}$ from 1994 onward.

\section{Discussion}

[18] The decade of MOZAIC in situ measurements now available provides unique insights into the composition and processes of the upper tropical troposphere. In this analysis of temperature, water vapor, and ozone at flight cruise levels in the tropics, we find greater seasonal variability for all three parameters in the South $\left(0-20^{\circ} \mathrm{S}\right)$ than in the North $\left(0-20^{\circ} \mathrm{N}\right)$ Tropics. There is remarkable coherence of the temperature profiles across seasons and in both tropics, with rms variances typically $<1^{\circ} \mathrm{C}$. The combined MOZAIC temperature anomalies $\left(20^{\circ} \mathrm{S}-20^{\circ} \mathrm{N}\right.$, for limited longitudes) agree well with the MSU channel 2 temperature anomalies for the whole tropics over the 112-month sampling period, indicating that the aircraft sampling (while missing the Pacific) does catch the large-scale interannual variations in the tropics. Use of MOZAIC data to help calibrate the longterm precision of the different MSU satellites over this period, however, would require more careful comparison using the actual geographic and temporal coverage.

[19] Water vapor is much more variable than temperature (i.e., scaling the relative anomalies with the Clausius-Clayperon relation). In terms of the seasonal cycle, the positive water vapor anomalies can be explained by consistent uplift in the summer hemisphere, while the negative anomalies are likely due to large-scale subsidence and/or extensive horizontal transport from the adjacent, dry subtropics. On longer timescales, the deseasonalized, interannual variations are not clearly connected to temperature. Given that these anomalies vary by a factor of 2.5 (peak-to-peak) and show multiyear correlations, no obvious trend in water vapor can be seen.

[20] Both the north and south tropics show clearly linear increases in ozone of a little more than $1 \mathrm{ppb} / \mathrm{yr}$. The trends are robust in spite of the MOZAIC sampling since they give similar results when calculated for restricted longitude ranges. There is no obvious correlation of $\mathrm{O}_{3}$ with the multiyear climatic variability that we see in temperature and water vapor. The tropical troposphere is thought to be very sensitive to anthropogenic perturbations. Lelieveld et al. [2004] attribute their reported increases in surface $\mathrm{O}_{3}$ over the tropical Atlantic to increasing industrial emissions of $\mathrm{NO}_{\mathrm{x}}$ and other $\mathrm{O}_{3}$ precursors in the tropics as well as in northern midlatitudes. Indeed, most model simulations of changing atmospheric composition under increasing burdens of air quality pollutants such as $\mathrm{NO}_{\mathrm{x}}, \mathrm{CO}, \mathrm{CH}_{4}$ and other hydrocarbons, predict the greatest global-scale increases in tropospheric $\mathrm{O}_{3}$ over the tropics and subtropics where pollution combines with active photochemistry (see the major chemistry-transport model assessments in the work of Prather et al. [2001], Stevenson et al. [2005], and F. Dentener et al., Global air quality for the next generation, submitted to Geophysical Research Letters, 2006, hereinafter referred to as Dentener et al., submitted manuscript, 2006).

[21] Can we understand the pattern and magnitude of tropospheric $\mathrm{O}_{3}$ increases over the last decade? Upward transport of both $\mathrm{O}_{3}$ and its precursors would tend to produce the largest increases (in terms of mole fraction) in the upper troposphere [e.g., Pickering et al., 1996, 1998]. Because tropospheric $\mathrm{O}_{3}$ is relatively long-lived in the upper troposphere and requires transport into the lower troposphere to be chemically removed, most model simulations show that pollution-driven trends are larger in the upper troposphere where $\mathrm{O}_{3}$ is also a more potent greenhouse gas. This pattern stands out in the IPCC assessments of 2001 [Prather et al., 2001] and 2007 [Stevenson et al., 2005; Denterer et al., submitted manuscript, 2006] and is likely the human fingerprint upon global air quality. The NASA GMI calculations for this latter assessment (B. Duncan, private communication, 2005) project future changes in tropospheric $\mathrm{O}_{3}$ of about $11 \mathrm{ppb}$ along the MOZAIC flight routes and $6 \mathrm{ppb}$ at the surface over the tropical Atlantic. While these changes match those of the MOZAIC decade, they are projected for the A2 scenario over the period 2000-2030, which has increases in annual $\mathrm{NO}_{\mathrm{x}}$ emissions of $27 \mathrm{Tg}-\mathrm{N} / \mathrm{yr}$, probably three times greater than that over the MOZAIC decade. Fusco and Logan [2003] also predict a zonal mean pattern of tropospheric $\mathrm{O}_{3}$ increase from 1970 to 1994 that is similar to the MOZAIC decade but only half as large. On the basis of increases in annual $\mathrm{NO}_{\mathrm{x}}$ emissions ( $\left.\sim 9 \mathrm{Tg}-\mathrm{N} / \mathrm{yr}\right)$, we might expect the 1970-1994 period to have similar $\mathrm{O}_{3}$ increases to the 1994-2003 MOZAIC decade. Thus while the pattern of tropical tropospheric $\mathrm{O}_{3}$ increases over the last decade fits our projections, the rate of increase is twice what was 
expected. Either we have greatly underestimated the increase in $\mathrm{O}_{3}$ precursors, particularly natural or anthropogenic $\mathrm{NO}_{\mathrm{x}}$ emissions or the atmosphere may be more sensitive than we anticipate to the global degradation of air quality.

[22] The patterns of variability and correlations in the MOZAIC measurements of temperature, water vapor, and ozone, shown here and in other analyses, are derived from a combination of chemistry, physics, large-scale dynamics, and mixing processes in the tropical troposphere. The unique properties of the MOZAIC data, specifically the high precision and spatial resolution available only from in situ measurements, can provide a stringent test for chemistry-transport models.

[23] Acknowledgments. The authors thank B. Duncan for analysis of the GMI projected ozone trends and J. Logan and A. Volz-Thomas for insight and constructive comments on the manuscript. We are indebted to the MOZAIC program and the whole investigator team for developing and maintaining an excellent climate data record of the upper troposphere and for making the data available (http://www.aero.obs-mip.fr/mozaic/). The MSU data used in this analysis are produced by Remote Sensing Systems, sponsored by the NOAA Climate and Global Change Program (www.remss.com). This research was supported at UC Irvine by the Jenkins Graduate Fellowship and by NASA grants in support of Atmospheric Chemistry and the Global Modeling Initiative.

\section{References}

Bremer, H., et al. (2004), Spatial and temporal variation of MOPITT CO in Africa and South America: A comparison with SHADOZ ozone and MODIS aerosol, J. Geophys. Res., 109, D12304, doi:10.1029/ 2003JD004234.

Chandra, S., J. R. Ziemke, and R. V. Martin (2003), Tropospheric ozone at tropical and middle latitudes derived from TOMS/MLS residual: Comparison with a global model, J. Geophys. Res., 108(D9), 4291, doi:10.1029/2002JD002912.

Christy, J. R., and R. W. Spencer (2000), MSU tropospheric temperatures: Dataset construction and radiosonde comparisons, J. Atmos. Ocean. Techol., 17, 1153-1170.

Fishman, J., and V. G. Brackett (1997), The climatological distribution of tropospheric ozone derived from satellite measurements using v7 TOMS and SAGE data sets, J. Geophys. Res., 102(D15), 19,275-19,278.

$\mathrm{Fu}, \mathrm{Q}$., and C. M. Johanson (2005), Satellite-derived dependence of tropical tropospheric temperature trends, Geophys. Res. Lett., 32, L10703, doi:10.1029/2004GL022266.

Fusco, A. C., and J. A. Logan (2003), Analysis of 1970-1995 trends in tropospheric ozone at Northern Hemisphere midlatitudes with the GEOSCHEM model, J. Geophys. Res., 108(D15), 4449, doi:10.1029/ 2002JD002742.

Gierens, K. M., U. Schumann, H. G. J. Smit, M. Helten, and G. Zäng1 (1997), Determination of humidity and temperature fluctuations based on MOZAIC data and parameterization of persistent contrail coverage for general circulation models, Ann. Geophys., 15, 1057-1066.

Goff, J. A., and S. Gratch (1946), Low-pressure properties of water from -160 to 212F, Trans. Am. Soc. Heat. Vent. Eng., 52, 95-122.

Held, I. M., and B. J. Soden (2000), Water vapor feedback and global warming, Annu. Rev. Energy Environ., 25, 441-475.

Helten, M., H. G. J. Smit, W. Straeter, D. Kley, and P. Nédélec (1998), Calibration and performance of automatic compact instrumentation for the measurement of relative humidity from passenger aircraft, J. Geophys. Res., 103(D19), 25,643-25,652.

Lelieveld, J., J. van Aardenne, H. Fischer, M. de Reus, J. Williams, and P. Winkler (2004), Increasing ozone over the Atlantic Ocean, Science, $304,1483-1487$.

Logan, J. A. (1999), An analysis of ozonesonde data for the troposphere: Recommendations for testing 3-D models and development of a gridded climatology for tropospheric ozone, J. Geophys. Res., 104(D13), $16,115-16,150$.

Logan, J. A., and V. W. J. H. Kirchhoff (1986), Seasonal variations of tropospheric ozone at Natal, Brazil, J. Geophys. Res., 91(D7), 78757881.

Logan, J. A., et al. (1999), Trends in the vertical distribution of ozone: A comparison of two analyses of ozonesonde data, J. Geophys. Res., 104(D21), 26,373-26,399.
Marenco, A., et al. (1998), Measurement of ozone and water vapor by Airbus in-service aircraft: The MOZAIC airborne program, An overview, J. Geophys. Res., 103(D19), 25,631-25,641.

Martin, R. V., D. J. Jacob, J. A. Logan, J. M. Ziemke, and R. Washington (2000), Detection of a lightning influence on tropical tropospheric ozone, Geophys. Res. Lett., 27(11), 1639-1642.

Mears, C. A., and F. J. Wentz (2005), The effect of diurnal correction on satellite-derived lower tropospheric temperature, Science, 309, 5740, 1548-1551, doi:10.1126/science. 1114772 .

Mears, C. A., M. Schabel, and F. J. Wentz (2003), A reanalysis of the MSU Channel 2 tropospheric temperature record, J. Climate, 16, 3650-3664, doi:10.1175/1520-0442.

Minschwaner, K., and A. E. Dessler (2004), Water vapor feedback in the tropical upper troposphere: Model results and observations, J. Climate, 17, $1272-1282$, doi:10.1175/1520-0442.

Peters, W., M. C. Krol, J. P. Fortuin, H. M. Kelder, A. M. Thompson, C. R. Becker, J. Lelieveld, and P. J. Crutzen (2004), Tropospheric ozone over a tropical Atlantic station in the Northern Hemisphere: Paramaribo, Surinam $\left(6^{\circ} \mathrm{N}, 55^{\circ} \mathrm{W}\right)$, Tellus, Ser. B, 56, 21-34.

Pickering, K. E., et al. (1996), Convective transport of biomass burning emissions over Brazil during TRACE A, J. Geophys. Res., 101(D19), 23,993-24,012.

Pickering, K. E., Y. Wang, W.-K. Tao, C. Price, and J.-F. Müller (1998), Vertical distributions of lightning NOx for use in regional and global chemical transport models, J. Geophys. Res., 103(D23), 31,20331,216 .

Prather, M., et al. (2001), Atmospheric chemistry and greenhouse gases, in Climate Change 2001: The Scientific Basis, edited by J. T. Houghton et al., pp. 239-287, chap. 4, Cambridge Univ. Press, New York.

Reid, G. C., K. S. Gage, and J. R. McAfee (1989), The thermal response of the tropical atmosphere to variations in Equatorial Pacific sea surface temperature, J. Geophys. Res., 94, 14,705-14,716.

Santer, B. D., et al. (2004), Identification of anthropogenic climate change using a second-generation reanalysis, J. Geophys. Res., 109, D21104, doi:10.1029/2004JD005075.

Santer, B. D., et al. (2005), Amplification of surface temperature trends and variability in the tropical atmosphere, Science, 309(5740), 1551-1556, doi:10.1126/science.1114867.

Sauvage, B., V. Thouret, J.-P. Cammas, F. Gheusi, G. Athier, and P. Nédélec (2005), Tropospheric ozone over Equatorial Africa: Regional aspects from the MOZAIC data, Atmos. Chem. Phys., 5, 311-335.

Seidel, D. J., R. J. Ross, J. K. Angell, and G. C. Reid (2001), Climatological characteristics of the tropical tropopause as revealed by radiosondes, J. Geophys. Res., 106(D8), 7857-7878.

Sherwood, S. C., J. R. Lanzante, and C. L. Meyer (2005), Radiosonde daytime biases and late-20th century warming, Science, 309(5740), 1556-1559, doi:10.1126/science. 1115640.

Soden, B. J., R. T. Wetherald, G. L. Stenchikov, and A. Robock (2002), Global cooling after the eruption of Mount Pinatubo: A test of climate feedback by water vapor, Science, 296, 727-730.

Stevenson, D. S., et al. (2005), Multimodel ensemble simulations of present-day and near-future tropospheric ozone, J. Geophys. Res., 110, doi:10.1029/2005JD006338, in press.

Stocker, T. F., et al. (2001), Physical climate processes and feedbacks, in Climate Change 2001: The Scientific Basis, edited by J. T. Houghton et al., pp. 723-727, chapter 4, Cambridge Univ. Press, New York.

Stohl, A., P. James, C. Forster, N. Spichtinger, A. Marenco, V. Thouret, and H. G. J. Smit (2001), An extension of the measurement of ozone and water vapour by Airbus in-service Aircraft (MOZAIC) ozone climatologies using trajectory statistics, J. Geophys. Res., 106(D21), $27,757-27,768$

Sun, D., and A. H. Oort (1995), Humidity-temperature relationships in the tropical troposphere, J. Clim., 8, 1974-1987, doi:10.1175/15200442 .

Thompson, A. M., K. E. Pickering, D. P. McNamara, M. R. Schoeberl, R. D. Hudson, J. H. Kim, E. V. Browell, V. W. J. H. Kirchhoff, and D. Nganga (1996), Where did tropospheric ozone over southern Africa and the tropical Atlantic come from in October 1992? Insights from TOMS, GTE TRACE A, and SAFARI 1992, J. Geophys. Res., 101(D19), 24,251-24,278.

Thompson, A. M., et al. (2003), Southern Hemisphere Additional Ozonesondes (SHADOZ) 1998-2000 tropical climatology: 2. Tropospheric variability and the zonal wave-one, J. Geophys. Res., 108(D2), 8241, doi:10.1029/2002JD002241.

Thouret, V., A. Marenco, P. Nédélec, and C. Grouhel (1998a), Ozone climatologies at $9-12 \mathrm{~km}$ altitude as seen by the MOZAIC airborne program between September 1994 and August 1996, J. Geophys. Res., 103(D19), 25,653-25,679.

Thouret, V., A. Marenco, J. Logan, P. Nédélec, and C. Grouhel (1998b), Comparisons of ozone measurements from the MOZAIC airborne pro- 
gram and the ozone sounding network at eight locations, J. Geophys. Res., 103(D19), 25,695-25,720.

Thouret, V., J.-P. Cammas, B. Sauvage, G. Athier, R. Zbinden, P. Nédélec, P. Simon, and F. Karcher (2005), Tropopause referenced ozone climatology and inter-annual variability (1994-2003) from the MOZAIC programme, Atmos. Chem. Phys. Disc., in press.

Vinnikov, K. Y., and N. C. Grody (2003), Global warming trend of mean tropospheric temperature observed by satellites, Science, 302(5643), $269-272$.

Ziemke, J. R., S. Chandra, and P. K. Bhartia (2005), A 25-year data record of atmospheric ozone in the Pacific from Total Ozone Mapping Spectrometer (TOMS) cloud slicing: Implication for ozone trends in the strato- sphere and troposphere, J. Geophys. Res., 110, D15105, doi:10.1029/ 2004JD005687.

S. E. Bortz and M. J. Prather, Earth System Science Department, University of California, Irvine, 2101 Croul Hall, Irvine, CA 92697-3100, USA. (bortz@uci.edu)

J.-P. Cammas and V. Thouret, Laboratorie d'Aérologie, CNRS, OMP, 14 Avenue E. Belin, F-31400 Toulouse, France.

H. Smit, Research Center, Jülich GmbH, Institute for Chemistry of the Polluted Atmosphere, P. O. Box 1913, D-52425 Jülich, Germany. 